\title{
Characterization of White and Black Deposits on the Surface of Korean Stone Cultural Heritages
}

\author{
Jiyoung Kim, ${ }^{1}$ Chan Hee Lee, ${ }^{1, *}$ Ran Hee Kim, ${ }^{1}$ and Eun Jeong Shin ${ }^{2}$ \\ ${ }^{1}$ Department of Cultural Heritage Conservation Sciences, Kongju National University, Shinkwan-dong 182, Gongju, \\ Chungnam Province 314-701, Republic of Korea \\ ${ }^{2}$ Conservation Science Division, National Research Institute of Cultural Heritage, Daejeon 305-380, Republic of Korea
}

\begin{abstract}
White and black deposits have been frequently observed on the surface of Korean stone cultural heritages, and they are considered as damage factors in both conservation and esthetic points of view. In order to set up the appropriate conservation remedy, it is important to know their origins, characteristics, and compositions. In this study, optical and scanning electron microscopes (SEMs) equipped with an energydispersive spectrometer (EDS) and X-ray diffractometer were employed to determine the white and black deposits. It was found that both deposits consisted mainly of calcium carbonate (calcite) and calcium sulfate (gypsum). The calcite and gypsum were characterized by bladed, rhombohedral, tabular, and amorphous morphologies under a SEM. The black deposit was not only composed of calcite or gypsum, but also accompanied amorphous and irregular matrix. SEM-EDS analysis revealed an abundance of silicon, aluminum, iron, phosphorus, and carbon on the matrix, which were major elements of soil, atmospheric deposits, and organisms. The white deposit, on the other hand, barely contained those coloring substances. These salts and deposited substances were caused by chemical reaction and physical adhesion between rock-forming minerals, lime mortar, sulfur in polluted air environment, soil dust, and microorganisms.
\end{abstract}

Key words: white, black, surface deposit, stone cultural heritage, SEM, EDS

\section{INTRODUCTION}

Stone cultural heritage occupies about $70 \%$ of the total number of Korean cultural heritage, which is designated as National and Provincial Heritage by the state and province. It has undergone natural and anthropogenic damage for a long period, as it is exposed to outdoor environment. The damage of stone cultural heritage is comprehensively studied and documented; it is generally known that there are three main factors of the damage, which are physical, chemical, and biological causes (Chesworth, 1971; Winkler, 1987; Camuffo, 1995; Warscheid \& Braams, 2000; Lee et al., 2003, 2005).

The chemical and biological factors, especially, result in the discoloration of the stone surface, such as blackening, whitening, browning, etc. These coloring materials not only cause secondary damage, but also esthetical interference of stone cultural heritage. Indeed, most conservation treatment has been carried out to remove the undesirable discoloring substances, and their removal by appropriate and efficient cleaning methods is one of the goals of conservation intervention.

White and black discolorations are the most frequently observed phenomena on the stone surface (Sabbioni, 1995; Moropoulou et al., 1998; Charola et al., 2007; Gaylarde et al., 2007; Török, 2008). The discoloring substances have various morphologies; they present a rigid, dense, and thick crust, or a thin layer of micro particle deposits which does not easily wash out. They also vary depending on orienta-

() MICROSCOPY SOCIETY OF AMERICA 2013

${ }^{\star}$ Corresponding author. E-mail: chanlee@kongju.ac.kr tion and position of the stone construction. It has been shown in previous studies that the principal types of deposits critically depend on the way in which the surface is wetted by rain (Camuffo, 1981; Grossi et al., 2003).

The various morphologies and colors of the deposits make it more difficult to find the causes and prevention, as well as removing solution. In order to set up the appropriate conservation remedy, it is important to know their origins, characteristics, and composition. This study aims to identify the white and black deposits based on the qualitative, quantitative, and morphological information.

\section{Materials And Methods}

For this study, 12 samples were collected from ten different stone cultural heritage sites; white deposits from Gyeongju Ice-Storing Warehouse (GJ), Andong Ice-Storing Warehouse (AD), Hyeonpung Ice-Storing Warehouse (HP), Seoul Hongjimun Floodgate (HJ), Seosan Rock-Carved Triad Buddha Statues (SM), Mireuksaji Stone Pagoda (MR), Bunhwangsa Stone Pagoda (BH), and Tapyeongri Stone Pagoda (TP), and black deposits from Changnyeong Ice-Storing Warehouse (CN), HP, HJ, SM, and Wongaksaji Pagoda (WG).

Each heritage is exposed to different environment; $\mathrm{HJ}$ and WG are located in a polluted urban area, whereas the others are set in unpolluted rural areas. They are composed of granite (GJ, $\mathrm{AD}, \mathrm{CN}, \mathrm{HP}, \mathrm{HJ}, \mathrm{SM}, \mathrm{MR}, \mathrm{TP})$, andesite $(\mathrm{BH})$, and marble (WG). Sample description for the study of cultural heritages is shown in Table 1.

The white and black deposits in $\mathrm{AD}, \mathrm{HJ}, \mathrm{MR}$, and $\mathrm{BH}$ presented thick and rigid crusts that are strongly adhered to 
Table 1. Sample Description for the Studied Korean Cultural Heritages.

\begin{tabular}{|c|c|c|c|c|}
\hline Heritage Names (Abbreviations) & $\begin{array}{l}\text { Construction } \\
\text { Ages }\end{array}$ & $\begin{array}{c}\text { Site } \\
\text { Environment }\end{array}$ & Host Rocks & Sample Descriptions \\
\hline Gyeongju Ice-Storing Warehouse (GJ) & 18th century & Rural & Granite & White deposit on the stone surface \\
\hline Andong Ice-Storing Warehouse (AD) & 18th century & Rural & Granite & $\begin{array}{l}\text { White thick and rigid crust strongly } \\
\text { adhered to the stone surface }\end{array}$ \\
\hline Changnyeong Ice-Storing Warehouse $(\mathrm{CN})$ & 18th century & Rural & Granite & $\begin{array}{l}\text { Black deposit occurred as a thin layer } \\
\text { along the stone boundaries }\end{array}$ \\
\hline Hyeonpung Ice-Storing Warehouse (HP) & 18th century & Rural & Granite & $\begin{array}{l}\text { White and black deposits occurring as } \\
\text { a foggy feature on the stone surface }\end{array}$ \\
\hline Seoul Hongjimun Floodgate $(\mathrm{HJ})$ & 18th century & Urban & Granite & $\begin{array}{l}\text { White and black thick crust on the } \\
\text { stone surface along the runoff }\end{array}$ \\
\hline Seosan Traid Buddha Statues (SM) & 7th century & Mountain & Granite & $\begin{array}{l}\text { White and black deposits along the } \\
\text { fissures }\end{array}$ \\
\hline Mireuksaji Stone Pagoda (MR) & 7th century & Rural & Granite & $\begin{array}{l}\text { White thick and rigid crust along the } \\
\text { stone boundaries }\end{array}$ \\
\hline Bunhwangsa StonePagoda (BH) & 7th Century & Rural & Andesite & $\begin{array}{l}\text { White crust strongly adhered to the } \\
\text { stone surface }\end{array}$ \\
\hline Tapyeongri Stone Pagoda (TP) & 8th century & Rural & Granite & $\begin{array}{l}\text { White thin crust along the irregular } \\
\text { cracks }\end{array}$ \\
\hline Wongaksaji Stone Pagoda (WG) & 15th century & Urban & Marble & $\begin{array}{l}\text { Black thick crust strongly adhered to } \\
\text { the stone surface with powdery soot }\end{array}$ \\
\hline
\end{tabular}

the stone surface (Figs. 1a-1d). The distribution can be found in wetted areas by the runoff, specifically remaining vertical traces (Fig. 1b). Those in the other heritages, on the other hand, occurred as a thin and foggy deposit or film (Figs. 1e, 1f).

In order to characterize the white and black deposits, X-ray diffraction (XRD), optical microscopy (OM), and scanning electron microscopy (SEM) analyses were carried out to obtain qualitatively the composition of the deposits and micromorphology. XRD analysis was performed with the use of a Bruker D8 Advance high-temperature X-ray diffractometer. The X-ray was $\mathrm{CuK} \alpha$ with $40 \mathrm{kV}$ and $40 \mathrm{~mA}$.

$\mathrm{OM}$ and SEM were applied on the samples using Nikon Eclipse E600W and JEOL JSM 6335, respectively. All samples for microscopic analysis were mounted in epoxy resin and polished. They were then coated by platinum for the application to SEM. X-ray analysis, using an energy-dispersive analyzer (Oxford), energy-dispersive X-ray spectrometer (Inca
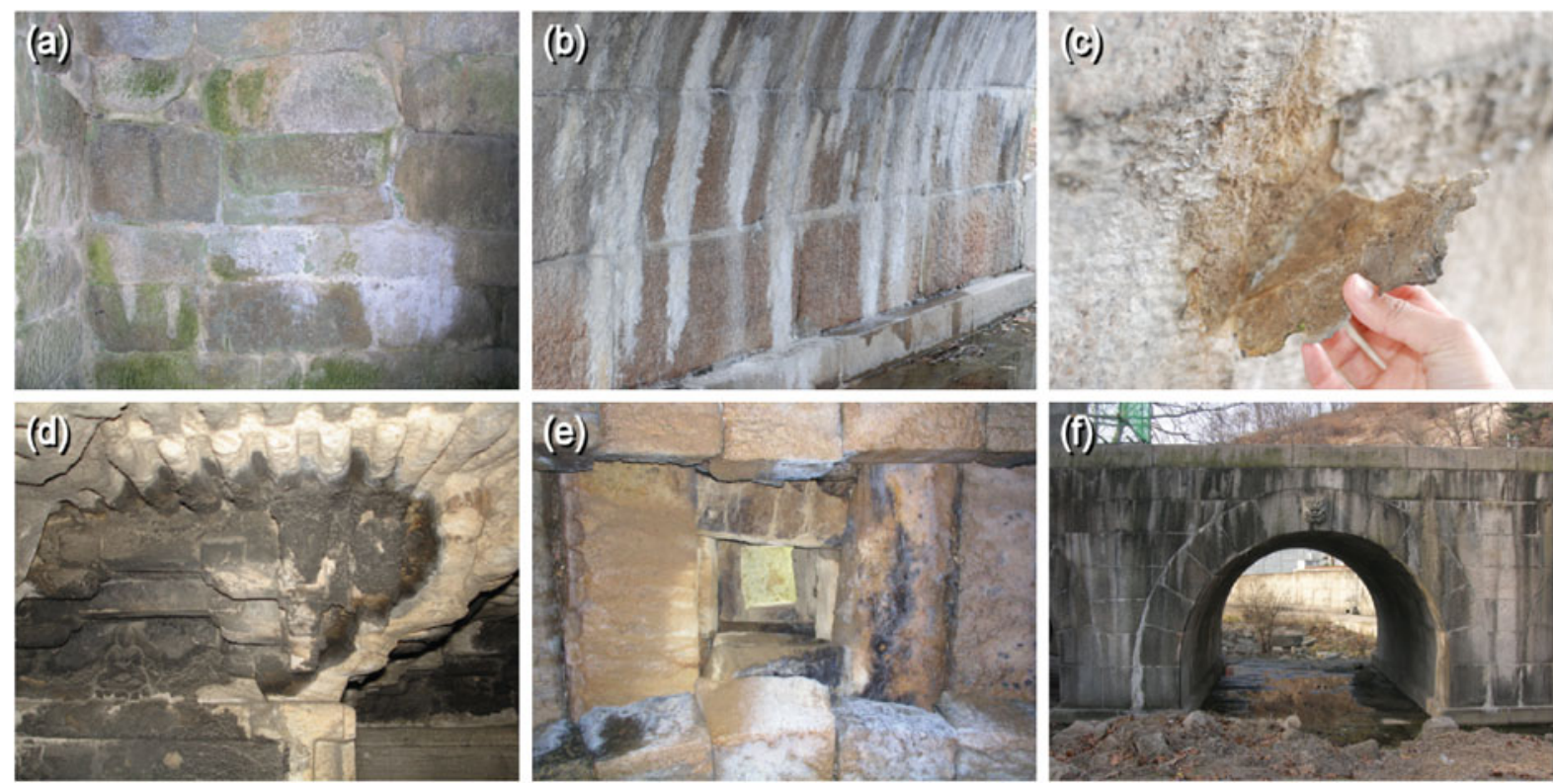

Figure 1. Occurrence of white and black deposits on the stone surface of some Korean cultural heritages. a: A white deposit in Andong Ice-Storing Warehouse. b, c: A thick white crust in Seoul Hongjimun Floodgate. d: A thick black crust in Wongaksaji Pagoda. e: A thin and foggy deposit in Changnyeong Ice-Storing Warehouse. f: An extensively thin black film along the runoff in Seoul Hongjimun Floodgate. 

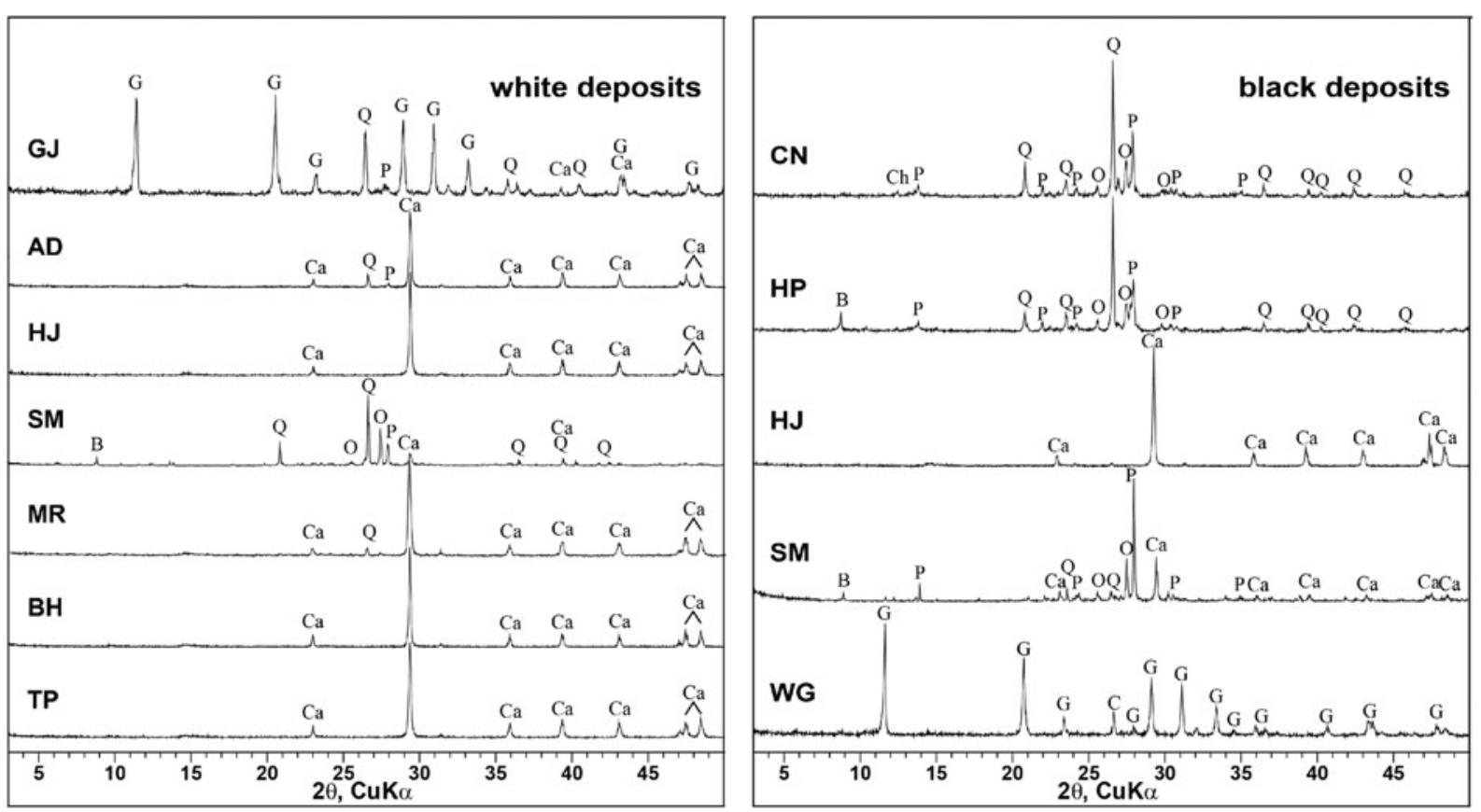

Figure 2. X-ray diffraction patterns of white and black deposits on the stone surface of some Korean cultural heritages. Q, quartz; O, orthoclase; P, plagioclase; B, biotite; Ca, calcite; G, gypsum; Ch, chlorite; C, graphitic carbon; AD, Andong Ice-Storing Warehouse; HJ, Seoul Hongjimun Floodgate; SM, Seosan Traid Buddha Statues, MR, Mireuksaji Stone Pagoda; BH, Bunhwangsa StonePagoda; TP, Tapyeongri Stone Pagoda; CN, Changnyeong Ice-Storing Warehouse; HP, Hyeonpung Ice-Storing Warehouse; WG, Wongaksaji Stone Pagoda.

$\mathrm{M} / \mathrm{X})$ attached to the SEM, also permitted qualitative element identification. Elemental mapping of the polished cross-sections also enabled further refinement of the occurrence of specific elements in the white and black deposits samples.

\section{Results}

Results of XRD analysis showed the presence of predominant calcite in the white deposits (Fig. 2). Gypsum also occurred in GJ accompanied by a small amount of calcite. The white deposit from SM mainly comprised quartz, plagioclase, orthoclase, and biotite, which are the rock-forming minerals of the original material of the granitic Buddha Statues. The black deposits presented high intensity of quartz, plagioclase, orthoclase, and biotite, as the deposit layers were extremely thin and the analyzed samples included a large portion of rock materials.

Calcite was detected in the samples from HJ and SM, indicating the major composition of the deposit. WG, however, predominantly comprised gypsum and minor carbon. The carbon was presumed as a cause of blackening of the deposit.

The results of XRD analysis showed that calcite and gypsum are the major compositions of white and black deposits. In addition, they were considered to be generated by foreign sources as the amount of calcite and gypsum in granite and andesite are negligible, and gypsum in marble as well. Both calcite $\left(\mathrm{CaCO}_{3}\right)$ and gypsum $\left(\mathrm{CaSO}_{4} \cdot 2 \mathrm{H}_{2} \mathrm{O}\right)$ are calcium-based salts and appear white in color. However, the diffraction patterns did not yield any difference between the white and black deposits, indicating black coloring substances except for graphitic carbon in WG. This could not be identified by XRD alone. Thus, surface analysis was conducted by microscopy.

Observations of the white deposit from AD with a stereoscopic microscope presented a dense and slightly ochercolored layer of $\sim 500 \mu \mathrm{m}$ in thickness, rarely combined with transparent quartz grains (Fig. 3a). This was mainly formed by unequigranular rhombohedral calcite under SEM, and the spaces between the calcite crystals were occupied by irregular micro particles (Fig. 3b). The white deposit from HP was found to consist of microorganisms (Fig. 3c).

The deposit on the HJ showed very diverse morphologies of star-like, rhombohedral, bladed, and tabular calcite (Figs. 3d-3f). EDS analysis detected a large amount of calcium and carbon, indicating the composition of calcite. In addition, a minor amount of silicon, aluminum, and iron was accompanied on the crystal surface (Table 2). Elemental distribution maps for the cross-section of $\mathrm{AD}$ revealed highly concentrated and uniform calcium deposit in the layer (Fig. 3m).

The black deposit, on the other hand, was not only composed of calcite and gypsum, but also significantly accompanied by amorphous and irregular matrix. The sample from WG showed hexagonal lamella to tabular and acicular gypsum crystals with granular particles in between (Figs. 3g, 3h). These particles contained silicon, calcium, sulfur, and carbon according to the result of EDS (Table 2). 

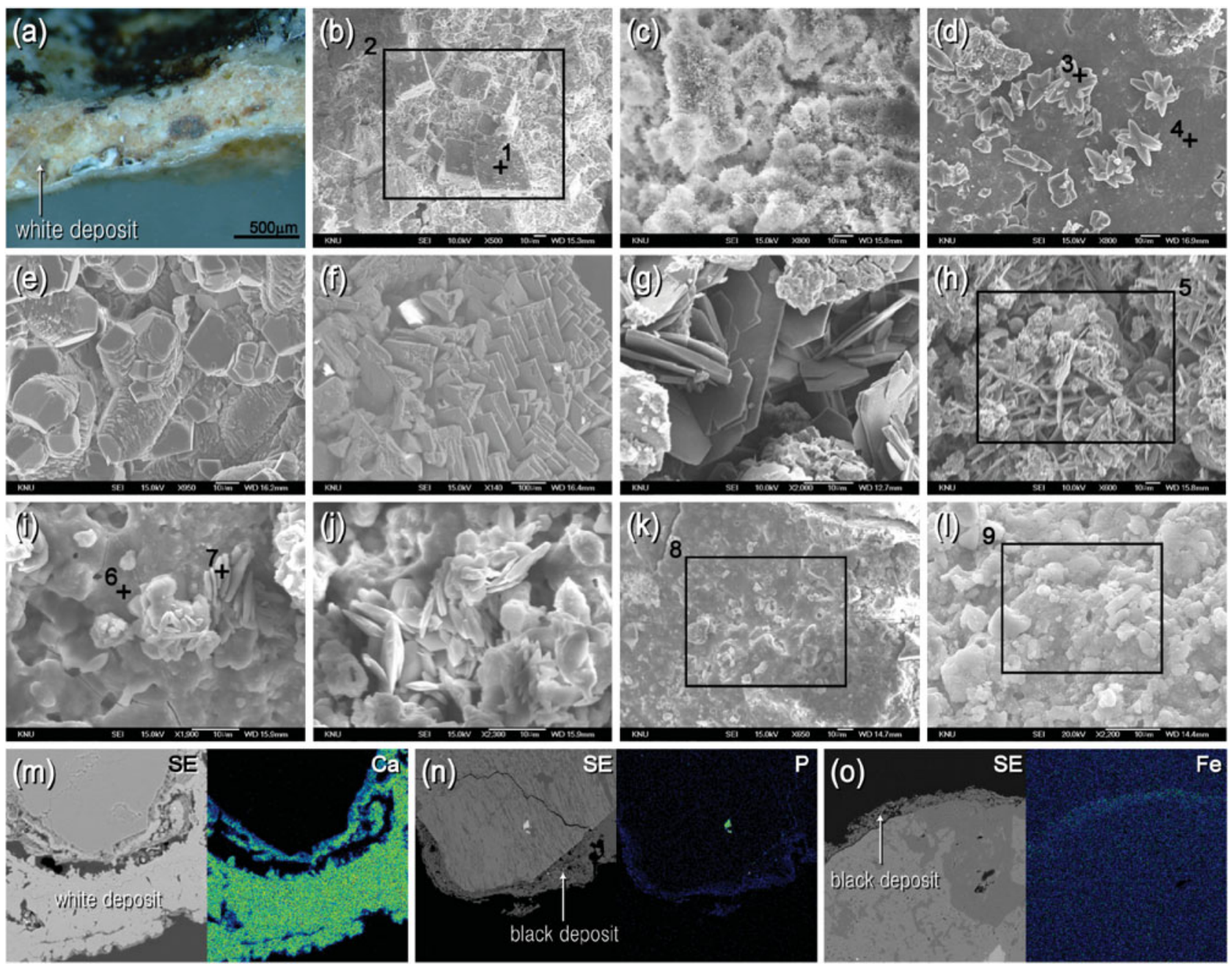

Figure 3. Stereoscopic, SEM, and EDS analysis results of white and black deposits. a: A cross-section of dense and slightly ocherous white deposit from AD. b: Unequigranular, rhombohedral, and euhedral crystals observed in white deposit of $\mathrm{AD}$. c: Microorganisms observed in the white deposit of HP. d: Star-like-shaped crystals of white HJ. e: Growth of subhedral crystals of the white deposit in HJ. f: Tabular crystals of the white deposit in HJ. g: Hexagonal lamella to tabular gypsum of the black deposit in WG. h: A complex of acicular gypsum and irregular particles of the black deposit in WG. i, j: Bladed gypsum aggregates with amorphous ground matrix of the black deposit in CN. $\mathbf{k}$, l: Irregular matrix without crystal formation of HP and HJ, respectively. m: SE image and calcium mapping for white AD by SEM-EDS. n, o: SE images, phosphor, and iron mappings for black CN by SEM-EDS. SEM, scanning electron microscopy; EDS, energy-dispersive spectrometry; AD, Andong Ice-Storing Warehouse; HP, Hyeonpung Ice-Storing Warehouse; HJ, Seoul Hongjimun Floodgate; WG, Wongaksaji Stone Pagoda; CN, Changnyeong Ice-Storing Warehouse; SE, secondary electron.

Table 2. SEM-EDS Analysis Results of White and Black Deposits (wt\%).

\begin{tabular}{|c|c|c|c|c|c|c|c|c|c|c|c|c|c|}
\hline Point & $\mathrm{SiO}_{2}$ & $\mathrm{Al}_{2} \mathrm{O}_{3}$ & $\mathrm{FeO}$ & $\mathrm{MgO}$ & $\mathrm{CaO}$ & $\mathrm{Na}_{2} \mathrm{O}$ & $\mathrm{K}_{2} \mathrm{O}$ & $\mathrm{TiO}_{2}$ & $\mathrm{P}_{2} \mathrm{O}_{5}$ & $\mathrm{ZrO}_{2}$ & $\mathrm{SO}_{3}$ & $\mathrm{CO}_{2}$ & Total \\
\hline Figure 3,1 & 7.5 & 4.3 & - & 1.6 & 60.3 & - & - & - & - & - & - & 26.3 & 100.0 \\
\hline Figure 3,2 & 15.9 & 8.9 & 5.8 & 1.0 & 19.4 & - & 0.8 & - & - & - & - & 48.2 & 100.0 \\
\hline Figure 3,3 & - & - & - & - & 67.5 & - & - & - & - & - & - & 32.5 & 100.0 \\
\hline Figure 3,4 & - & - & - & - & 52.8 & 1.9 & 2.2 & - & - & - & 2.6 & 40.5 & 100.0 \\
\hline Figure 3,5 & 19.2 & - & - & - & 17.8 & - & - & - & - & - & 34.8 & 28.2 & 100.0 \\
\hline Figure 3,6 & 43.8 & 16.2 & 13.5 & 0.5 & 5.4 & 0.4 & 1.9 & 0.7 & 1.6 & 9.8 & 6.2 & - & 100.0 \\
\hline Figure 3,7 & 4.6 & 2.6 & 4.9 & 0.2 & 38.6 & 0.2 & 0.6 & 0.3 & - & 8.0 & 40.0 & - & 100.0 \\
\hline Figure 3,8 & 42.6 & 11.6 & 0.8 & 0.3 & 0.5 & 0.3 & 0.5 & - & - & - & - & 43.4 & 100.0 \\
\hline Figure 3,9 & 7.0 & 2.7 & - & - & 44.3 & - & - & - & - & - & - & 46.0 & 100.0 \\
\hline
\end{tabular}

SEM, scanning electron microscope; EDS, energy-dispersive spectrometer. 
The detection of carbon corresponded to the results of the diffraction pattern. It was observed that blade gypsum aggregates occurred on porous matrix throughout the deposit in the black deposit from CN (Figs. 3i, 3j). Silicon, aluminum, and iron were detected in the matrix, whereas the gypsum was characterized by calcium and sulfur, which are chemical compositions of the mineral (Table 2).

In the cross-section of the $\mathrm{CN}$ sample, it was found that phosphor and iron were more concentrated in the black layer than the original stone material (Fig. 3n). On the other hand, the deposits from HP and HJ appeared amorphous and irregular substances without definite mineral forms (Figs. 3k, 31). The composition of the deposit taken in $\mathrm{HP}$ was very similar to that of the matrix of $\mathrm{CN}$ by EDS analysis, whereas the one taken in Seoul Hongjimun Floodgate indicated calcite (Table 2).

\section{Discussion And Conclusions}

Calcite and gypsum found in both white and black deposits were interpreted to be foreign substances, which barely compose the studied stone cultural heritages except for marble of Wogaksaji Pagoda. They could be easily produced by chemical reactions between Ca-rich materials, atmospheric carbon, and sulfur.

The $\mathrm{AD}, \mathrm{HJ}, \mathrm{MR}$, and $\mathrm{BH}$ have been extensively reconstructed using Portland cement and concrete before. The other studied stone cultural heritages were also partially restored by those Ca-based materials in the past. These mortars are interpreted to supply abundant calcium source (Lee et al., 2008). WG, which showed an extremely concentrated gypsum crust, exceptionally, has a calcium source in the stone itself. In addition, the pagoda is exposed to polluted air environment, which produces a lot of sulfur, fly ash, and soot. Thus, these sources are considered to cause a thick and black crust on the stone surface (Guido et al., 1997; Bugini et al., 2000; Maravelaki-Kalaitzaki, 2005).

The difference between the white and black deposits was identified to be attributable to the matrix exhibited on the outer surface of the deposits. SEM-EDS results depicted that the black deposits consisted of comparatively larger amounts of silicon, aluminum, and iron, and more diverse elements such as sodium, potassium, zircon, phosphor, and carbon than the white deposits. These elements are typical constituents of soil and organisms, indicating that the black deposits were derived from them and caused dark discoloring on the stone surface (Wright, 2002; Gaylarde et al., 2007). In conclusion, it was confirmed that SEM and EDS techniques were efficient in characterizing the surface deposits on the stone cultural heritage by means of morphological and spectrometric analyses.

\section{ACKNOWLEDGMENT}

This study was supported by the Research and Development Budget of National Research Institute of Cultural Heritages in Korea.

\section{REFERENCES}

Bugini, R., Tabasso, M.L. \& Realini, M. (2000). Rate of formation of black crusts on marble. J Cult Herit 1, 111-116.

Camuffo, D. (1981). Hot horse anemometry. Atmos Environ 15, 1767.

Camuffo, D. (1995). Physical weathering of stones. Sci Total Environ 167, 1-14.

Charola, A.E., Pühringer, J. \& Steiger, M. (2007). Gypsum: A review of its role in the deterioration of building materials. Environ Geol 52, 339-352.

Chesworth, W. (1971). The major element geochemistry and the mineralogical evolution of granitic rocks during weathering. In Origin and Distribution of Elements, Ahrens, L.H. (Eds.), pp. 305313. Oxford, UK: Pergamon Press.

Gaylarde, C.C., Ortega-Morales, B.O. \& Bartolo-Pérez, P. (2007). Biogenic black crusts on buildings in unpolluted environment. Curr Microbiol 54, 162-166.

Grossi, C.N., Esbert, R.M., Diaz-Pache, F. \& Alonso, F.J. (2003). Soiling of building stones in urban environments. Build Environ 38, 147-159.

Guido, C.G., Paola, B., Darinn, C., Guiseppe, C. \& Rocco, M. (1997). Chemical characterization of the black crust present on the stone central portal of St. Denis abbey. Anal Bioanal Chem 357, 1211-1214.

Lee, C.H., Choi, S.W. \& SuH, M. (2003). Natural deterioration and conservation treatment for the granite standing Buddha of Daejosa Temple, Republic of Korea. Geotech Geol Eng 21, 63-77.

Lee, C.H., Lee, M.S., Suh, M. \& Choi, S.W. (2005). Weathering and deterioration of rock properties of the Dabotap pagoda (World Cultural Heritage), Republic of Korea. Environ Geol 47, 547-557.

Lee, D.S., Lee, C.H., Kim, J. \& YAng, H.J. (2008). Geochemical characteristics of surface efflorescence on the seventh century stone pagoda in Republic of Korea. Environ Geol 58, 197-204.

Maravelaki-Kalaitzaki, P. (2005). Black crusts and patinas on Pentelic marble from the Parthenon and Erechtheum (Acropolis, Athens): Characterization and origin. Anal Chim Acta 532, 187-198.

Moropoulou, A., Bisbikou, K., Torfs, K., Van Grieken, R., ZezzA, F. \& Marci, F. (1998). Origin and growth of weathering crusts on ancient marbles in industrial atmosphere. Atmos Environ 32, 967-982.

SABbioni, C. (1995). Contribution of atmospheric deposition to the formation of damage layers. Sci Total Environ 167, 49-55.

TöröK, A. (2008). Black crusts on travertine: Factors controlling development and stability. Environ Geol 56, 583-594.

Warscheid, T. \& BraAms, J. (2000). Biodeterioration of stone: A review. Int Biodeter Biodegr 46, 343-368.

WinkLER, E.M. (1987). Weathering and weathering rates of natural stone. Environ Geol 9, 85-92.

Wright, J.S. (2002). Geomorphology and stone conservation: Sandstone decay in Stoke-on-Trent. Struct Surv 20, 50-61. 